\title{
Alien plant species and factors of invasiveness of anthropogenic vegetation in the Northwestern Balkans - a phytosociological approach
}

\section{Research Article}

Urban Šilc ${ }^{1, *}$, Sava Vrbničanin², Dragana Božić2 ${ }^{2}$ Andraž Čarni ${ }^{1}$, Zora Dajić Stevanović²

'Institute of Biology,

Scientific Research Centre of the Slovenian Academy

of Sciences and Arts,

SI-1000 Ljubljana, Slovenia

2Faculty of Agriculture,

University of Belgrade,

11080 Belgrade, Serbia

Received 22 December 2011; Accepted 06 March 2012

Abstract: We studied the anthropogenic vegetation of the Northwest Balkans in order to determine its susceptibility to invasion by alien plant species. We compiled a dataset of 3089 vegetation plots sampled between 1939 and 2009, recording a set of variables for each sample plot in order to determine which factors have the most effect on a habitat's vulnerability to invaders. We calculated the proportion of native species, archaeophytes and neophytes for each plot. We used regression tree models to determine the site conditions of the most invaded anthropogenic habitats. The sample plots contained an average of $12.7 \%$ alien plant species, with a low proportion of archaeophytes (4.3\%) and $8.4 \%$ neophytes. Local habitat conditions proved to have the largest effect, rather than climatic variables or propagule pressure. The proportion of archaeophytes follows a different pattern than that seen in central and northern Europe, indicating that macroecological factors are more important. Neophytes show a similar distribution to other European locations.

Keywords: Archaeophytes $\bullet$ Neophytes $\bullet$ Regression tree $\bullet$ Mediterranean phytogeographical region $\bullet$ Continental phytogeographical region (c) Versita Sp. z 0.0 .

\section{Abbreviations}

EIV - ecological indicator values;

PCA - Pr incipal Components Analysis;

GLM - General Linear Model;

C\&RT - Classification and Regression Trees.

\section{Introduction}

Recent years have seen extensive research into biological invasion [1-3], reflecting the increasing global problem of alien species. The occurrence of alien plant species (divided, based on immigration time, into archeophytes and neophytes [4]) differs according to ecosystem characteristics. Anthropogenic vegetation is generally the most invaded habitat type [2-8], due to strong disturbance and management. However, there are also differences because the disturbance differs according to a region's areal extent, magnitude, frequency, predictability and turnover rate [9]; this results in patchy habitats at different successional stages.

Invasive species are considered to be the second largest reason for biodiversity loss world-wide [10] and, in recent years, national and international environmental policy and legislation have begun to reflect this fact. In central and southeast Europe, risks originating from alien species - particularly with regard to the negative impact on the biodiversity of native species - seem to represent a huge problem. However, this relationship is scale dependant so is not straightforward [11-13].

Recent studies on alien plant species tend to use vegetation plot data $[5,8,11,12,14-16]$, but large-scale quantitative sets of species distribution are scarce. It has been shown that the use of phytosociological relevés (the same methodology of sampling over a larger area and long time period) is more accurate than floristic grid mapping due to the smaller scale 
of samples [5] on different scales. This method also benefits from the additional information represented by species abundance data. The abundance and cover of alien species captures more information than simple presence/absence data, since many invasive plant species form mono-dominant communities in natural vegetation. This becomes important for conservation managers because the cover of alien species, rather than their number, has the most significant effect on native species' diversity [17].

There have been some studies on alien plant species in the northwest Balkans, primarily at the species level and at regional scales. Most of them have dealt with economically important invasive weeds [18-20] or with new alien species often of casual occurrence [21,22]. In contrast with northern parts of Europe or even some parts of the Mediterranean region, less attention has been paid to alien flora in general and especially to the level of invasion of particular habitats with different environmental conditions.

In the current study, we have focused on the degree to which alien plants invade man-made habitats in the northwest Balkans. The study area, comprising a Mediterranean region and its bordering Continental region, allows alien species occurrence to be considered on a regional scale where previous studies only compare distinct regions [5]. The social and political system is also consistent across the study region. The main questions of our study were: (a) Which man-made habitats are most invaded? (b) Which environmental variables best explain invasion by archaeophytes and neophytes? (c) What differences in environmental conditions affect alien species invasion according to phytogeographical region (Continental vs. Mediterranean)?

\section{Experimental Procedures}

\subsection{Material}

For the purpose of analysis, we compiled a large dataset of vegetation relevés from the northwest Balkans (former Yugoslavia) that considered annual and perennial ruderal vegetation of man-made habitats (arable fields were excluded). In total, 3589 vegetation relevés were entered into the Turboveg database [23]. Vegetation relevés were assigned to syntaxa on the basis of the original author's classification.

In order to avoid oversampling, we randomly selected only five relevés of one syntaxon from one locality made by a single author. In order to exclude relevés whose species composition deviated by more than two standard deviations, we used Outlier Analysis in PC-ORD 5 [24]. This left 3089 relevés with 1366 species from the northwest Balkans recorded between 1939 and 2009.

In order to describe the salient environmental conditions in each sample plot, we determined variables that correspond to regional climatic conditions, local habitat conditions and anthropogenic pressure as a surrogate for propagule pressure. Population variables and GDP were used for the latter.

We obtained the following variables for each plot:

- Altitude (m)

- Annual mean temperature $\left({ }^{\circ} \mathrm{C}\right)$

- Annual precipitation (mm/year)

- Population (number of inhabitants in a municipality)

- Population density (inhabitants/km²)

- Gross domestic product - GDP (in former Yugoslavian dinars per municipality)

- Proportion of urban and rural population (\%) Phytogeography according to Horvatić [25].

Climatic variables (annual temperature and precipitation) were obtained from Hijmans et al. [26] from www.worldclim.org. Statistical data for the municipalities of ex-Yugoslavia (523 municipalities) were taken from the Statistical Yearbook [27].

Classification of species with respect to residence time into archaeophytes and neophytes was done according to [4] and [28]. A plant species was designated an archaeophyte if it was classified as such in at least one area (state) and a neophyte if it was classified as a neophyte and not as an archaeophyte. Local lists of flora were used for classification [20,29-31].

For each plot, we calculated ecological indicator values (EIV) [32]. These were used to represent the environmental conditions of the habitat; as such, only species that were native to each plot were used when calculating the EIV.

The life strategies of plant species were taken from to Grime [33]. Three main categories - C (competitor), $R$ (ruderals), and $\mathrm{S}$ (stress tolerators) - and a further four intermediate categories were taken from the database BIOLFLOR [34]. The proportion of $C, S$ and $R$ was calculated for each plot from the complete species list.

All taxa that were determined only to a genus level, as well as all bryophytes, were deleted. Species nomenclature followed Flora Europaea [35]. The nomenclature of syntaxa follows Mucina et al. [36].

The dataset was further subdivided into two subsets (Mediterranean and Continental) according to the phytogeographical affiliation of a single plot (Figure 1). The Mediterranean subset comprised of 631 plots; the Continental, 2458 plots.

\subsection{Methods}

Ordination analysis (Principal Components Analysis, PCA) was used to show the relationship between 
selected environmental variables. A plot by variables matrix was used in the program CANOCO 4.5 [37].

We used the General Linear Model (GLM) to determine the relationship between the proportion of alien species (archaeophytes and neophytes) and individual environmental variables. With partial analyses, we were able to calculate the variation of the proportion of alien species explained by an individual environmental variable and its partial effect, by removing the influence of all other variables from the analysis.

Classification and Regression trees (C\&RT) were used to predict continuous dependent variables and to find the relationships between the ratio of alien species and environmental variables [38]. This method algorithmically determines a set of split conditions in tree nodes that allow accurate prediction of cases. Data mining reveals simple relationships between variables without a priori knowledge. Data are split into two mutually exclusive groups that are homogeneous as far as possible: meaning that the response variable is minimized in within-group variation. Each group was split further based on a single explanatory variable. In order to determine when to stop splitting cases and to obtain an optimal tree size, we used 10 -fold crossvalidation with the S.E. rule $=1$ [39].

In each node, we used surrogate predictors that also predict the splitting of cases (in addition to the primary splitting variable) and enable explanation of the pattern of variation in the dataset. We used 0.3 as an associated value to consider the surrogate valid.

The STATISTICA 8.0 program [40] was used for univariate statistics, GLM and regression tree analyses.

\section{Results}

Principle component analysis (PCA) of plots $x$ environmental variables shows the grouping of environmental variables and their relationships (Figure 2). The number of inhabitants, gross domestic product (GDP) and proportion of urban population were correlated with the first axis. Altitude and rural population are also related to each other, while annual temperature is correlated with population, GDP and urban population. In contrast, annual precipitation is negatively correlated with the latter group of variables.

All vegetation plots (relevés) together contained 1366 species and the proportion of alien plant species was $12.7 \%$; the proportion of archaeophytes $4.3 \%$ and neophytes $8.4 \%$. The proportion of alien species (Figure 3) significantly differs among the three time periods (Kruskall-Wallis ANOVA, $\mathrm{H}=75.17508$, $\mathrm{P}<0.001)$. In the proportion of archaeophytes, there are

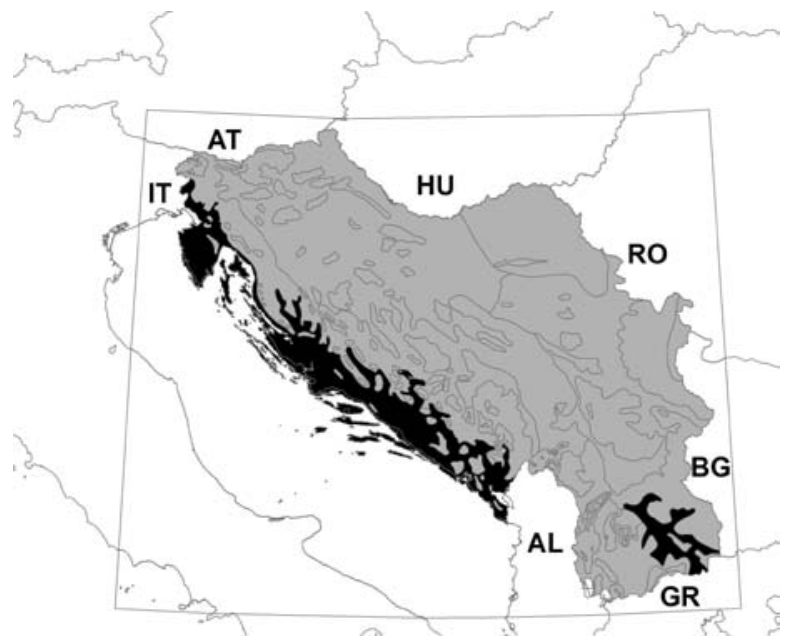

Figure 1. Research area divided into two phytogeographical regions (black, Mediterranean; grey, continental), per Horvatić [25]

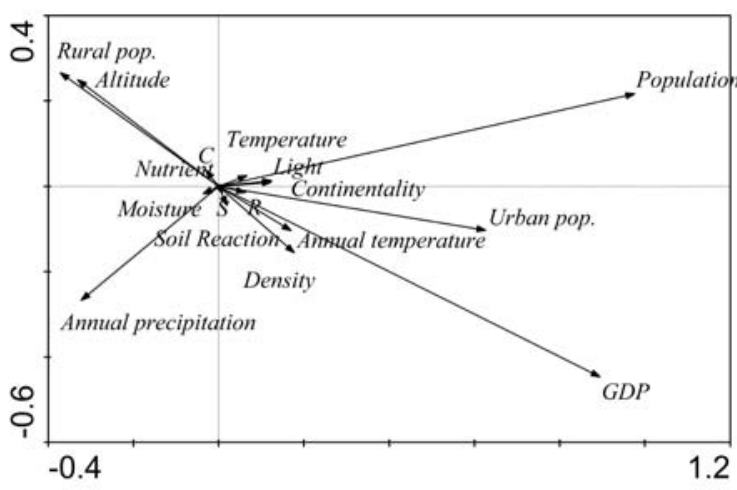

Figure 2. Environmental variables in the Principal Components Analysis (PCA) ordination diagram, calculated on the basis of the correlation matrix.

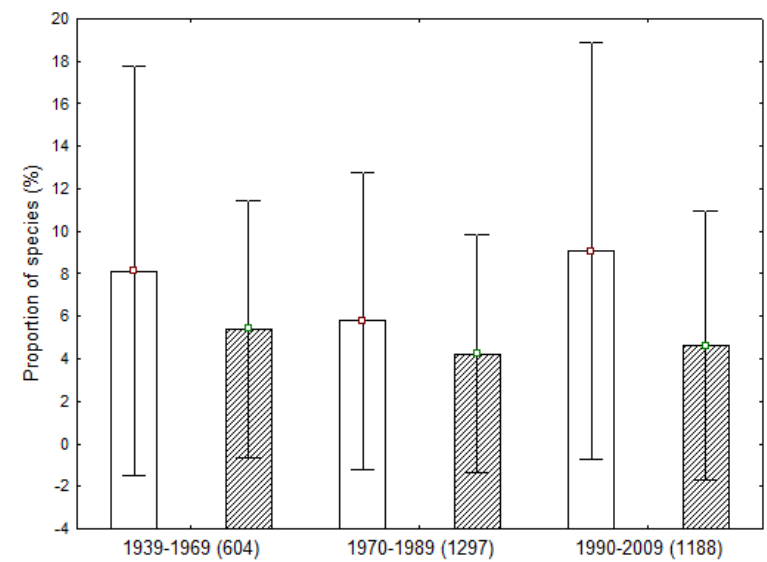

Figure 3. Proportion of alien species in anthropogenic vegetation across three periods in the northwestern Balkans. Number along the sampled period indicates number of plots. Archaeophytes - empty column, neophytes hatched column. 
differences between the first and the last two periods, while in the proportion of neophytes, only the first and the last period are not significantly different.

The highest proportion of alien species (Table 1) was in annual ruderal vegetation (class Stellarietea mediae), followed by perennial ruderal vegetation (Artemisietea), and the lowest proportion was in perennial nitrophilous vegetation (Galio-Urticetea) and trampled vegetation (Polygono-Poetea). A low proportion of archaeophytes was especially evident in the last two vegetation types - strikingly low in semi-natural vegetation on the banks of rivers (order Convolvuletalia sepium). The lowest proportion of neophytes was in semi-natural mesophilous and nitrophilous perennial communities (Lamio-Chenopodietalia boni-henrici). The highest proportion of archaeophytes and neophytes was found in thermophilous grass-rich ruderal vegetation on dry sandy soils (order Eragrostietalia).

The most common archaeophyte was Malva sylvestris, with a high frequency in all four vegetation types. In contrast, neophytes differed among vegetation classes. Matricaria discoidea was most frequent in trampled vegetation, Erigeron annuus, Conyza canadensis and Ambrosia artemisiifolia were mostly found in the class Artemisietea. In annual ruderal vegetation, Conyza canadensis was most the frequent species but Portulaca oleracea, Amaranthus retroflexus and Conyza bonariensis appeared in the order Eragrostietalia. Solidago gigantea, Fallopia japonica and Echinocystis lobata were abundant in nitrophilous perennial ruderal vegetation (class Galio-Urticetea), especially in vegetation along rivers (order Convolvuletalia sepium).

The regression tree (Figure 4), explaining the proportion of archaeophytes in man-made vegetation, shows the first split into two groups based on EIV temperature, EIV nutrients, EIV moisture, EIV light, proportion of competitors and ruderals and annual mean temperature. Approximately equally-sized groups split on the temperature gradient, and further nodes are based mostly on the proportion of ruderals and competitors, while the two terminal nodes are based on the proportion of stress tolerators.

The optimal regression tree, explaining the proportion of neophytes (Figure 5), divides the vegetation plots based on annual mean temperature (higher than $9.25^{\circ} \mathrm{C}$ ) and altitude (lower than $431 \mathrm{~m}$ ). The group of 2146 plots then splits according to the proportion of ruderal and competitor species. Two thirds of plots have a lower proportion of ruderal species and the next node splits a low number of highly nutrient rich plots. A group of 729 plots with a higher proportion of neophytes occurs in sites with a high proportion of competitors. In the next splitting, most thermophilous vegetation plots with a high neophyte proportion subdivide. In the first node, a group of 943 plots with a lower proportion of neophytes further divides according to the ruderality of the site.

The relationship of the proportion of archaeophytes (Table 2) was strong for climatic variables and some site conditions (EIV for moisture and nutrients). The proportion of neophytes was strongly related to altitude and GDP and nutrient rich sites. Both types of alien species were related to the proportion of ruderals in the stands. Correlations are relatively low, but comparable to similar studies [6].

The general variation of the proportion of archaeophytes was explained by the proportion of stress tolerant species, followed by the EIV value

\begin{tabular}{l|ccccc}
\hline & No. of plots & Plot area $\left(\mathrm{m}^{2}\right)$ & Species richness & Archaeophytes (\%) & Neophytes (\%) \\
\hline \hline Polygono-Poetea & 572 & $16.31 \pm 17.50$ & $12.61 \pm 5.43$ & $2.47 \pm 4.72$ & $7.49 \pm 8.32$ \\
Stellarietea mediae & 861 & $26.01 \pm 25.54$ & $19.05 \pm 8.27$ & $7.47 \pm 7.17$ & $10.42 \pm 10.45$ \\
Eragrostietalia & 147 & $22.26 \pm 25.60$ & $15.21 \pm 6.31$ & $\mathbf{1 2 . 0 3} \pm \mathbf{8 . 5 9}$ & $\mathbf{1 7 . 3 6} \pm \mathbf{1 1 . 0 3}$ \\
Chenopodietalia muralis & 135 & $16.77 \pm 14.21$ & $21.10 \pm 7.09$ & $9.18 \pm 6.29$ & $12.67 \pm 11.57$ \\
Sisymbrietalia & 579 & $27.30 \pm 24.21$ & $21.03 \pm 9.23$ & $7.36 \pm 6.50$ & $8.12 \pm 8.40$ \\
Artemisietea & 893 & $31.43 \pm 28.06$ & $24.21 \pm 9.59$ & $4.32 \pm 5.04$ & $6.07 \pm 6.53$ \\
Onopordetalia acanthii & 809 & $29.83 \pm 26.41$ & $23.26 \pm 8.35$ & $4.66 \pm 5.35$ & $5.48 \pm 6.23$ \\
Agropyretalia intermedio-repentis & 84 & $37.31 \pm 29.12$ & $19.25 \pm 9.52$ & $3.29 \pm 4.57$ & $6.63 \pm 6.65$ \\
Galio-Urticetea & 763 & $21.55 \pm 19.66$ & $20.36 \pm 6.81$ & $2.42 \pm 4.03$ & $5.19 \pm 7.89$ \\
Lamio albi-Chenopodietalia boni-henrici & 585 & $22.05 \pm 21.97$ & $21.16 \pm 7.77$ & $2.10 \pm 3.75$ & $\mathbf{3 . 8 7} \pm \mathbf{5 . 3 4}$ \\
Convolvuletalia sepium & 178 & $31.18 \pm 29.29$ & $20.69 \pm 9.06$ & $\mathbf{1 . 7 0} \pm \mathbf{2 . 9 5}$ & $12.42 \pm 11.87$ \\
\hline
\end{tabular}

Table 1. Anthropogenic vegetation types and their characteristics. The number of plots in the analysis, plot area, number of plant species per plot and ratio of archaeophytes and neophytes and standard deviations are presented. Minimum and maximum proportions of alien species are presented in bold. 


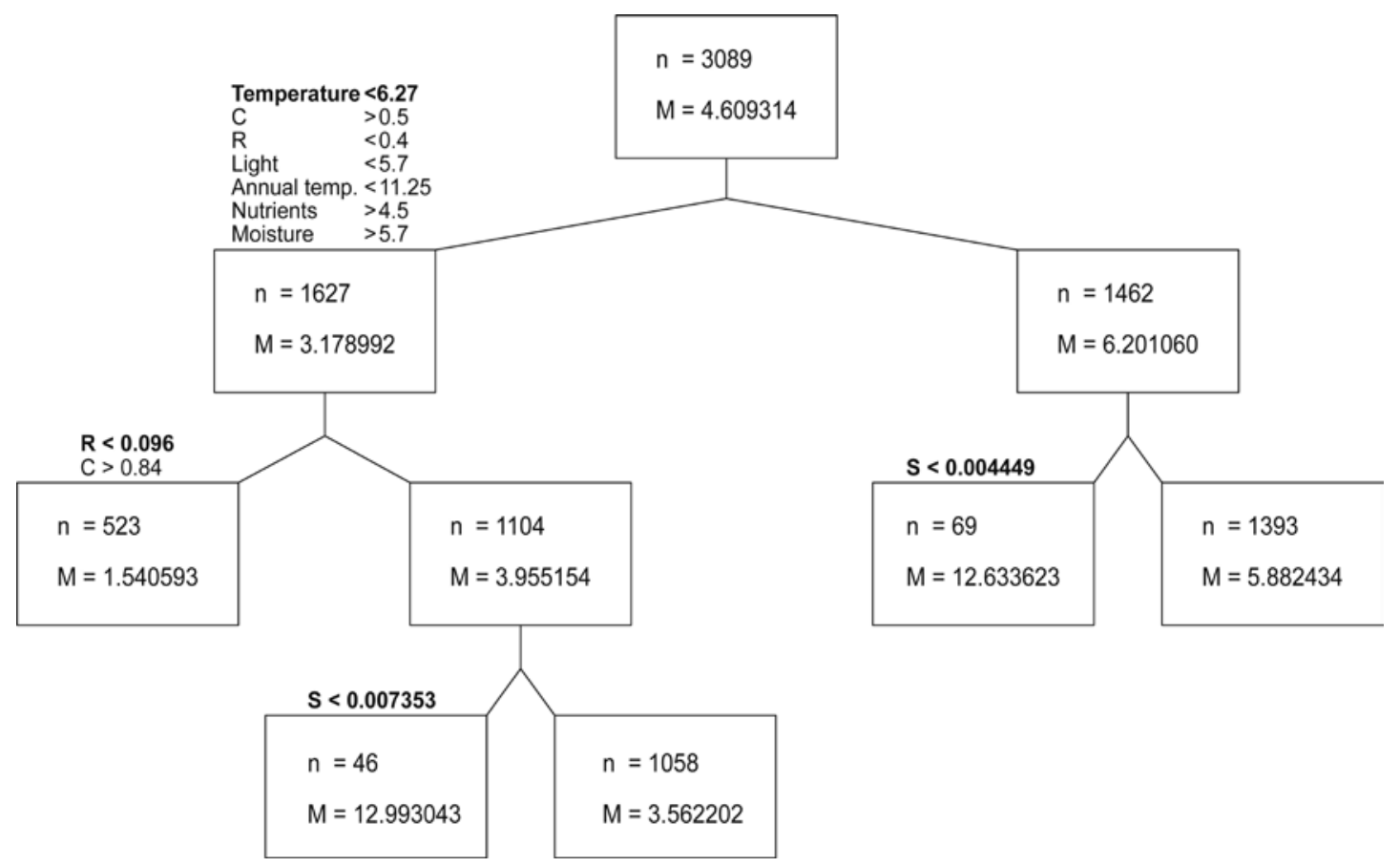

Figure 4. Regression tree accounting for the proportion of archaeophytes in anthropogenic vegetation of the NW Balkans. Each node is represented by a split variable (in bold) and its value, number of plots in the node (n) and mean percentage of archaeophytes (M). Further surrogate predictors in each node are listed. The tree explained $35.81 \%$ of variation.

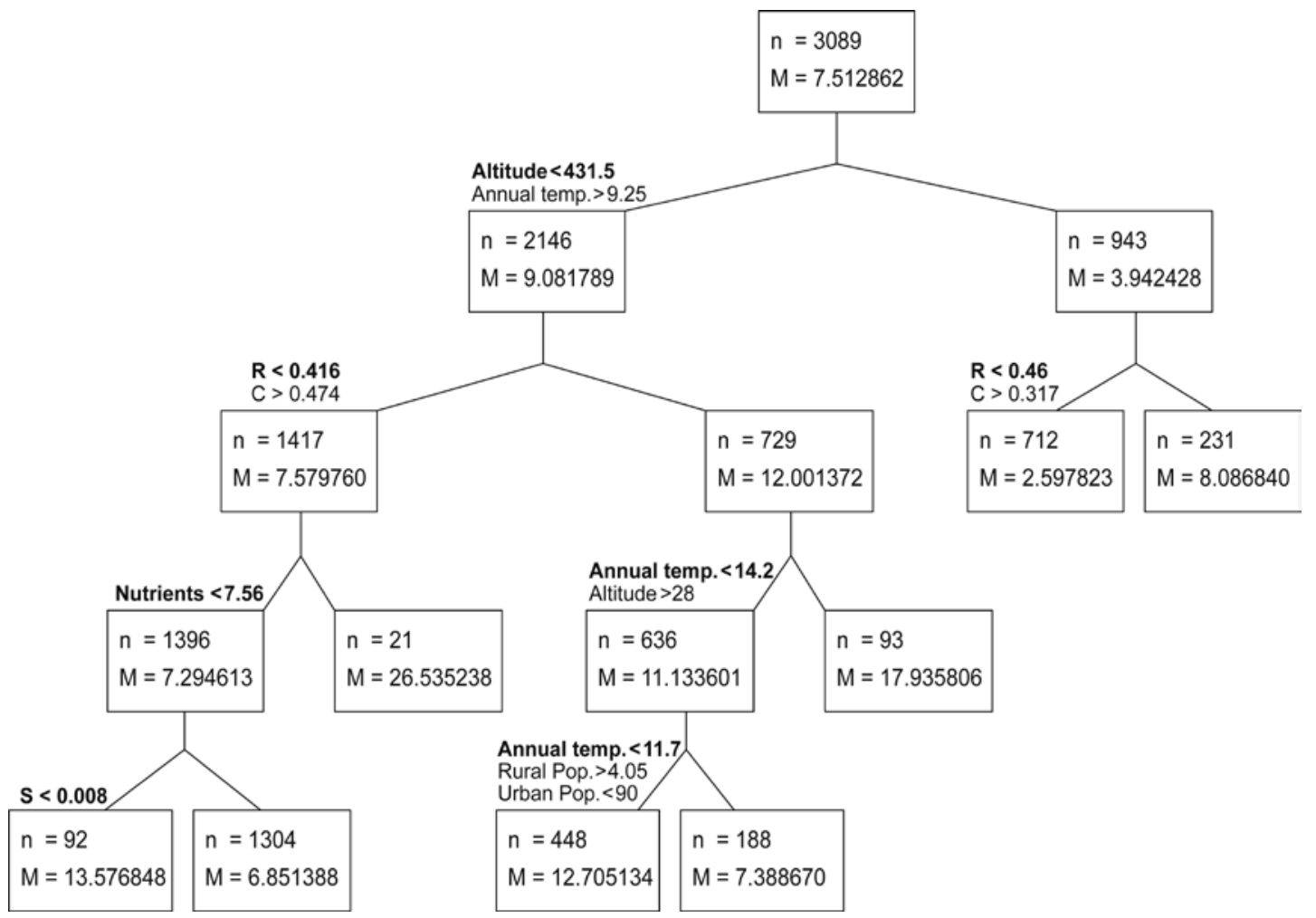

Figure 5. Regression tree explaining the proportion of neophytes in anthropogenic vegetation of the NW Balkans. Each node is represented by a split variable (in bold) and its value, number of plots in the node (n) and mean percentage of neophytes (M). Further surrogate predictors in each node are listed. The tree explained $77.92 \%$ of variation. 


\begin{tabular}{|c|c|c|c|c|c|c|}
\hline & \multicolumn{3}{|c|}{ Ratio archeophytes } & \multicolumn{3}{|c|}{ Ratio neophytes } \\
\hline & Beta in & Partial & $\mathrm{P}$ & Beta in & Partial & $\mathrm{P}$ \\
\hline Altitude & 0.030 & 0.018 & n.s. & -0.276 & -0.167 & ** \\
\hline Urban population & -0.052 & -0.033 & n.s. & -0.026 & -0.017 & n.s. \\
\hline Rural population & -0.048 & -0.032 & n.s. & -0.103 & -0.070 & ** \\
\hline Population density & 0.011 & 0.011 & n.s. & 0.003 & 0.003 & n.s. \\
\hline Population & -0.070 & -0.041 & * & -0.067 & -0.040 & * \\
\hline GDP & 0.092 & 0.051 & * & 0.178 & 0.102 & ** \\
\hline Annual mean temperature & 0.176 & 0.095 & $\star *$ & -0.097 & -0.055 & * \\
\hline Annual precipitation & -0.070 & -0.053 & * & 0.003 & 0.002 & n.s. \\
\hline \multicolumn{7}{|l|}{ Life strategies } \\
\hline Competitors & 0.052 & 0.023 & n.s. & -0.016 & -0.007 & n.s. \\
\hline Stress tolerators & -0.081 & -0.070 & $\star \star$ & -0.117 & -0.104 & ** \\
\hline Ruderals & 0.181 & 0.094 & $\star \star$ & 0.192 & 0.103 & $* *$ \\
\hline \multicolumn{7}{|c|}{$\begin{array}{l}\text { Ellenberg indicator values (EIV) } \\
\text { for native species }\end{array}$} \\
\hline Light & 0.003 & 0.002 & n.s. & 0.016 & 0.012 & n.s. \\
\hline Temperature & 0.093 & 0.060 & $\star *$ & 0.110 & 0.074 & ** \\
\hline Continentality & -0.021 & -0.018 & n.s. & 0.009 & 0.008 & n.s. \\
\hline Moisture & -0.184 & -0.115 & $\star *$ & 0.034 & 0.022 & n.s. \\
\hline Soil Reaction & 0.007 & 0.006 & n.s. & -0.005 & -0.005 & n.s. \\
\hline Nutrients & 0.160 & 0.115 & $* *$ & 0.150 & 0.111 & $* *$ \\
\hline
\end{tabular}

Table 2. Results of the General Linear Model of the relationship between the proportion of archaeophytes and neophytes and environmental variables. Beta is the standard regression coefficient between the respective variable and the dependent variable, Partial is after controlling for all other independent variables in the equation. ${ }^{*} \mathrm{P}<0.001,{ }^{*} \mathrm{P}<0.05$, n.s. - not significant.

for temperature. In the case of neophytes, the most important variables were the proportion of ruderal species, GDP and EIV for nutrients.

Division of the data-set into two subsamples from the Continental and Mediterranean regions showed some differences. There is significantly (Mann-Whitney $U$ test, $z=-11.39, P<0.001$ ) higher species richness, with more archeophytes in the Continental part, while the number of neophytes differs less significantly $(z=1.98$, $\mathrm{P}<0.05)$. Comparison of the ratio of neophytes shows no differences, while the ratio of archeophytes differs significantly $(z=-11.40, P<0.001)$, being higher in the Continental part (6.80\% vs. $4.04 \%)$.

In the Mediterranean region, the urban population is important in determining the ratio of archeophytes and neophytes. Temperature (EIV) and nutrients (EIV) are important for neophytes, while archaeophytes are found in communities with more light. In the Continental region, neophytes are found in areas with higher GDP.

Some differences are evident in a comparison of the occurrence of the same type of alien species in different phytogeographical regions (Table 3). Archaeophytes in the Mediterranean are indifferent to annual temperature, while in the Continental region, annual temperature plays a role on a regional and local scale. For neophytes, ecological conditions are more similar (nutrient rich, warm sites) but sites with a higher ratio of neophytes are more disturbed in the Mediterranean region.

\section{Discussion}

\subsection{Proportion of alien species}

Human influenced habitats usually harbour a large proportion of alien species. However, this fact is strongly influenced by the scale of sampling units (vegetation plot, city, state) [6,14] and by the latitudinal and altitudinal gradient [12]. Many studies dealing with alien flora have mainly used grid data [41-45] and results are not comparable to the results of studies in which flora was sampled in habitat plots $[6,14,16]$.

Flora of human influenced vegetation in the Balkans consists of $4.3 \%$ of archaeophytes, comparable with Italy, whereas the proportion of archaeophytes is 


\begin{tabular}{cc|cc}
\hline Archaeophytes & Variable rank & Neophytes & Variable rank \\
\hline \hline S-strategy & 100 & R-strategy & 100 \\
EIV-Temperature & 77 & S-strategy & 95 \\
R-strategy & 72 & GDP & 89 \\
EIV-Moisture & 71 & ElV-Nutrients & 84 \\
Annual mean temperature & 70 & Altitude & 61 \\
C-strategy & 60 & Population & 66 \\
Altitude & 59 & C-strategy & 63 \\
EIV-Light & 58 & EIV-Continentality & 62 \\
EIV-Continentality & 42 & Urban population & 61 \\
EIV-Nutrients & 35 & Population density & 58 \\
Annual precipitation & 29 & Rural population & 50 \\
Urban population & 26 & ElV-Light & 48 \\
Rural population & 23 & EIV-Temperature & 46 \\
Population density & 21 & Annual mean temperature & 44 \\
Population & 18 & ElV-Moisture & 31 \\
GDP & 16 & Annual precipitation & EIV-Soil Reaction \\
EIV-Soil Reaction & 10 & & \\
\hline
\end{tabular}

Table 3. The ranking of importance of variables derived from regression tree analysis for archaeophytes and neophytes separately.

much higher in Central Europe. It ranges from 21.8\% in trampled vegetation to $47.3 \%$ in annual ruderal vegetation [14] or $31.9 \%$ in man-made habitats [6]. On the other hand, the proportion of archaeophytes in Great Britain is comparable, at $6.7 \%$ [5].

The proportion of neophytes more closely resembles habitats elsewhere in Europe. In the northwest Balkans' anthropogenic habitats it is $8.4 \%$, similar to results from man-made habitats in Central Europe $(9.6 \%$ for annual ruderal vegetation [14], 7.3\% [6]), the Atlantic (4.5\%) and the Mediterranean (5.3\%) [5]. Neophytes are generally more abundant in urban habitats $[46,47]$. Neophytes are mostly thermophilic plants that find suitable conditions (less frosty days, higher temperatures) in urban habitats in continental Europe, while such sites are widely distributed in the landscape in the southern part of Europe.

\subsection{Importance of various factors on the level of invasion}

The level of invasion (as the proportion of alien species in a habitat) depends on biogeographic, climatic, economic and demographic factors [12]. We therefore used several proxies to characterize the habitats with the highest proportion of archaeophytes and neophytes.

Plant strategies indicate habitat characteristics. Plant strategy has a strong predictive power with respect to the proportion of each alien plant type in anthropogenic vegetation; climatic variables were less important, and the influence of propagule pressure was even less important. Pyšek et al. [12], who used vegetation data and habitat characteristics on a smaller scale, found these factors to have the same relative influence on the proportion of alien species. Human influence (e.g., wealth and demography) seemed to have more effect when considering data of all alien taxa from Europe; nevertheless, when restricting the data to plant species, climate and insularity have a strong effect [12].

Life strategies [33] were used to indicate disturbance regimeand stress. Man-made habitats and anthropogenic vegetation are a product of human influence that is best represented by various disturbances [8] and is indicated by a higher proportion of R-strategists. We found a positive relationship between the ratio of alien species and ruderal strategies. A similar pattern was found in Central European anthropogenic vegetation [6], while in Slovenia, strictly R-strategists were confined to arable land and CSR strategists to ruderal vegetation in the narrower sense [8]. The habitats with the highest level of invasion are strongly and frequently disturbed by high pulses of nutrient (resource) availability [12].

Another informative result was a negative correlation between proportion of aliens and S-strategists, showing that aliens avoid man-made habitats with high stress; in the case 
of the Balkan Peninsula, these are mostly warm and dry habitats. This is also confirmed by the negative correlation between archaeophytes and EIV-moisture value.

\subsection{Differences between archaeophytes and neophytes}

There are differences between patterns of archaeophytes and neophytes in man-made habitats in central Europe and southern Europe. Archaeophytes originate from the Mediterranean basin or the Near East $[48,49]$ and have expanded their range with the spread of agriculture; as such, their proportion increases towards northern parts of Europe, because many of them are native to southern Europe (or else their status is doubtful) [43].

Archaeophytes are more influenced by habitat conditions indicated by stress tolerators (indicating low availability of resources) and EIV-temperature and ruderals as indicators of disturbance (Table 3). Compared to Central Europe [6], climatic (mean annual temperature and altitude) factors are more highly ranked, showing that these species are more similar to native species $[42,50]$. The importance of stress tolerant species and the proportion of archaeophytes are both probably linked to the warm and dry habitats of their home environmental conditions, with low productivity. Studies from Northern [51] and Central Europe [6,15] have shown a closer relationship between the ratio of archaeophytes and disturbance, which was explained by evolutionary history and long adaptation to disturbance through agriculture. In contrast, researchers in Southeast Europe [52] found a prevalence of competitive types (C) for archaeophytes and their occurrence in ruderal vegetation. Archaeophytes with a different strategy and occurrence in segetal habitats are extinct or declining.

\begin{tabular}{|c|c|c|c|c|c|c|c|c|c|c|c|c|}
\hline & \multicolumn{5}{|c|}{ Mediterranean } & & \multicolumn{6}{|c|}{ Continental } \\
\hline & \multicolumn{3}{|c|}{$\begin{array}{c}\text { Ratio } \\
\text { archeophytes }\end{array}$} & \multicolumn{3}{|c|}{ Ratio neophytes } & \multicolumn{2}{|c|}{$\begin{array}{l}\text { Ratio } \\
\text { archeophytes }\end{array}$} & \multicolumn{4}{|c|}{ Ratio neophytes } \\
\hline & Beta in & Partial & $P$ & Beta in & Partial & $P$ & Beta in & Partial & $P$ & Beta in & Partial & $P$ \\
\hline Altitude & -0.221 & -0.109 & $\star \star$ & -0.259 & -0.133 & ** & 0.074 & 0.042 & * & -0.262 & -0.158 & ** \\
\hline Urban population & -0.119 & -0.100 & * & 0.150 & 0.132 & $\star \star$ & -0.023 & -0.013 & n.s. & -0.104 & -0.062 & ** \\
\hline Rural population & -0.164 & -0.107 & $\star \star *$ & 0.051 & 0.035 & n.s. & -0.008 & -0.005 & n.s. & -0.128 & -0.087 & ** \\
\hline Population density & 0.016 & 0.017 & n.s. & -0.027 & -0.029 & n.s. & 0.011 & 0.010 & n.s. & 0.015 & 0.015 & n.s. \\
\hline Population & 0.005 & 0.003 & n.s. & 0.075 & 0.039 & n.s. & -0.081 & -0.045 & * & -0.057 & -0.034 & n.s. \\
\hline GDP & -0.051 & -0.024 & n.s. & -0.091 & -0.046 & n.s. & 0.134 & 0.072 & ** & 0.245 & 0.139 & ** \\
\hline Annual mean temperature & -0.047 & -0.022 & n.s. & -0.010 & -0.005 & n.s. & 0.123 & 0.068 & ** & -0.059 & -0.035 & n.s. \\
\hline Annual precipitation & -0.077 & -0.043 & n.s. & 0.149 & 0.088 & * & -0.068 & -0.050 & * & 0.026 & 0.020 & n.s. \\
\hline \multicolumn{13}{|l|}{ Life strategies } \\
\hline Competitors & 0.037 & 0.023 & n.s. & 0.147 & 0.094 & * & 0.035 & 0.011 & n.s. & -0.319 & -0.110 & ** \\
\hline Stress tolerators & -0.079 & -0.073 & n.s. & -0.057 & -0.056 & n.s. & -0.093 & -0.067 & ** & -0.228 & -0.171 & ** \\
\hline Ruderals & 0.227 & 0.184 & $\star *$ & 0.376 & 0.310 & ** & 0.164 & 0.056 & ** & -0.116 & -0.042 & * \\
\hline \multicolumn{13}{|c|}{$\begin{array}{l}\text { Ellenberg indicator values } \\
\text { (EIV) for native species }\end{array}$} \\
\hline Light & 0.147 & 0.101 & * & -0.088 & -0.064 & n.s. & -0.022 & -0.016 & n.s. & 0.034 & 0.025 & n.s. \\
\hline Temperature & 0.019 & 0.010 & n.s. & 0.319 & 0.186 & ** & 0.100 & 0.072 & ** & 0.078 & 0.060 & ** \\
\hline Continentality & 0.012 & 0.012 & n.s. & 0.052 & 0.052 & n.s. & -0.009 & -0.007 & n.s. & 0.006 & 0.005 & n.s. \\
\hline Moisture & -0.229 & -0.126 & $\star \star$ & -0.008 & -0.005 & n.s. & -0.149 & -0.105 & ** & 0.048 & 0.036 & n.s. \\
\hline Soil Reaction & 0.117 & 0.101 & * & 0.143 & 0.128 & $\star \star$ & -0.017 & -0.016 & n.s. & -0.025 & -0.025 & n.s. \\
\hline Nutrients & 0.138 & 0.097 & * & 0.174 & 0.128 & $* *$ & 0.162 & 0.122 & $* *$ & 0.133 & 0.107 & $* *$ \\
\hline
\end{tabular}

Table 4. Results of the General Linear Model of the relationship between the proportion of archaeophytes and neophytes and environmental variables in two separate datasets (Mediterranean and Continental). Beta in is the standard regression coefficient between the respective variable and the dependent variable, Partial is after controlling for all other independent variables in the equation. ${ }^{* *} P<0.001,{ }^{*} P<0.05$, n.s. - not significant. 
The pattern of neophytes is similar to that observed in other parts of Europe. Broad-scale environmental conditions are not hugely important for the proportion of neophytes, although neophytes are more confined to warm habitats (annual temperature higher than $9.2^{\circ} \mathrm{C}$ ). Habitat conditions and propagule pressure are more important. In the Balkan Peninsula, amonghabitat characteristics, disturbance and EIV-nutrients denote more invaded habitats, while in Central Europe, this is true of sites with EIV-light, indicating that neophytes invade open sites [6] that are again the product of disturbance. Altitude plays an important role in neophyte invasions. This could be a function of temperature, and in the comparison with archaeophytes this could also be related to propagule pressure. The proportion of neophytes is higher in more urbanized areas (in correlation with a less rural population and higher GDP). Pyšek et al. [12] showed that human population density and economic wealth are major factors determining the invasion of species and are more important than environmental factors (climate, geography, land cover, etc.).

\subsection{Differences in phytogeography}

Chytrý et al. [5] have already reported that alien flora is more similar between different habitats within the same region than between the same habitats of different regions. Dissimilarity between the two regions (Continental and Mediterranean) was therefore expected.

In the Continental part, the proportion of alien plants is correlated negatively with S-strategists and positively with GDP (an indicator of urbanity). A similar pattern emerges when comparing of archaeophytes and neophytes, but archaeophytes are more confined to warmer parts of the region and drier habitats and are generally found at higher altitudes. In the Mediterranean, neophytes are more thermophilic than archaeophytes which require drier habitats. Generally, alien plants require soils with a higher $\mathrm{pH}$, and more heavily-disturbed sites.

\section{References}

[1] Perrings C., Dehnen-Schmutz K., Touza J., Williamson M., How to manage biological invasions under globalization, Trends Ecol. Evol., 2005, 20, 212-215

[2] Rejmánek M., Richardson D.M., Pyšek P., Plant invasions and invasibility of plant communities, In: van der Maarel E. (Eds.), Vegetation Ecology, Blackwell Science, Oxford, 2005

[3] Hulme P.E., Biological Invasions in Europe: Drivers, Pressures, States, Impacts and Responses, In:
The Mediterranean region is less invaded than temperate Europe [53], but a high level of invasion is still evident on the coast and in larger urban areas. Gasso et al. [44] designate these areas as hot spots of invasive plant richness. Our data of man-made habitats are from such areas and therefore show a similar level of invasion to those of the more temperate inland regions. This difference is mainly due to the lack of archaeophytes in the Mediterranean region.

The Continental region shows a significant relationship between proportion of alien species propagule pressure. Chytrý et al. [5] have shown the effect of propagule pressure to be lower than the effect of habitat characteristics. When comparing temperate and Mediterranean regions, we showed the environment to be more important in the latter. This may be because the analysis was restricted to man-made habitats, and because a high susceptibility to aliens is linked to disturbed habitats in both regions.

By analysing a large vegetation database, we identified major patterns of alien species occurrence and compared them to other parts of Europe. The pattern of neophytes is similar in the northwest Balkans to the rest of Europe, and is most strongly influenced by site conditions, whereas climate is the more important factor affecting archaeophyte abundance. When comparing Mediterranean and Continental regions, some differences emerge in the absence of archaeophytes in the first region, while in the second region, site (nutrients and disturbance) is most important.

\section{Acknowledgements}

We are grateful to L. Topalić-Trivunović and S. Petronić, who helped us with collecting the literature data. We also thank I. Sajko for producing the map and data extraction in GIS. Martin Cregeen improved the English. This project was funded from ARRS L1-6517 and the Ministry of Education and Science of the Republic of Serbia (Project III 046008).

Hester R.E., Harrison R.M. (Eds.), Biodiversity Under Threat, RSC Publishing, Cambridge, 2007

[4] Pyšek P., Richardson D.M., Rejmánek M., Webster G.L., Williamson M., Kirschner J., Alien plants in checklists and floras: towards better communication between taxonomists and ecologists, Taxon, 2004, 53, 131-143

[5] Chytrý M., Maskell L.C., Pino J., Pyšek P., Vilà M., Font X., et al., Habitat invasions by alien plants: 
a quantitative comparison among Mediterranean, subcontinental and oceanic regions of Europe, J. Appl. Ecol., 2008, 45, 448-458

[6] Simonová D., Lososová Z., Which factors determine plant invasions in man-made habitats in the Czech Republic?, Perspect. Plant. Ecol., 2008, 10, 89-100

[7] Thiele J., Kollmann J., Andersen U.R., Ecological and Socioeconomic Correlates of Plant Invasions in Denmark: The Utility of Environmental Assessment Data, AMBIO, 2009, 38, 89-94

[8] Šilc U., Synanthropic vegetation: pattern of various disturbances on life history traits, Acta Bot. Croat., 2010, 69, 215-227

[9] Sousa W.P., The role of disturbance in natural communities, Ann. Rev. Ecol. Syst., 1984, 15, 353391

[10] Vitousek P.M., D’Antonio C.M., Loope L.L., Westbrooks R., Biological invasions as global environmental change, Am. Sci., 1996, 84, 468-478

[11] Vilà M., Pino J., Font X., Regional assessment of plant invasions across different habitat types, J. Veg. Sci., 2007, 18, 35-42

[12] Pyšek P., Jarošík V., Hulme P.E., Kühn I., Wild J., Arianoutsou M., et al., Disentangling the role of environmental and human pressures on biological invasions across Europe, Proc. Natl. Acad. Sci. USA, 2010, 107, 12157-12162

[13] Comin S., Ganis P., Poldini L., Vidali M., A diachronic approach to assess alien plant invasion: The case study of Friuli Venezia Giulia (NE Italy), Plant Biosyst., 2011, 145, 50-59

[14] Chytrý M., Pyšek P., Tichý L., Knollová I., Danihelka J., Invasions by alien plants in the Czech Republic: a quantitative assessment across habitats, Preslia, 2005, 77, 339-354

[15] Pyšek P., Jarošík V., Residence time determines the distribution of alien plants, In: Inderjit S. (Ed.), Invasive plants: ecological and agricultural aspects, Birkhäuser Verlag-AG, Basel, 2005

[16] Jansen F., Ewald J., Zerbe S., Ecological preferences of alien plant species in North-Eastern Germany, Biol. Invasions, 2011, 13, 2691-2701

[17] Crall A.W., Newman G.J., Stohlgren T.J., Jarnevich C.S., Evangelista P., Geuenther D., Evaluating dominance as a component of non-native species invasions, Divers. Distrib., 2006, 12, 195-204

[18] Kovačević J., Distribution of northamerican weed ragweed (Ambrosia artemisiifolia L.) in weed communities of Central Posavina[Rasprostranjenost sjevernoameričkog korova limundžika (Ambrosia artemisifolia L.) u korovskim fitocenozama Srednje Podravine], Godišnjak Biološkog instituta Sarajevo, 1957, 10, 173-176 (in Serbian)
[19] Šilc U., Odontito-Ambrosietum Jarolímek et al. 1997 - a ruderal association new to Slovenia, Acta Bot. Croat., 2002, 61, 179-198

[20] Vrbničanin S., Karadžić B., Dajić-Stevanović Z., Adventive and invasive weed species in Serbia, Acta biologica iugoslavica - serija G: Acta herbologica, 2004, 13, 1-12

[21] Slavnić Ž., About immigration, spreading and naturalisation of some adventive plants in Bosnia and Herzegovina [O useljavanju, širenju i odomađivanju nekih adventivnih biljaka u Bosni i Hercegovini], Godišnjak Biološkog instituta Univerziteta u Sarajevu, 1960, 12, 117-143 (in Serbian)

[22] Trinajstić I., Contribution to knowledge of distribution of species Reynoutria japonica Houtt. (Polygonaceae) in Yugoslavia [Prilog poznavanju rasprostranjenosti vrste Reynoutria japonica Houtt. (Polygonaceae) u Jugoslaviji], Fragmenta herbologica lugoslavica, 1990, 19, 139-143 (in Croatian)

[23] Hennekens S. M., Schaminée J.H.J., TURBOVEG, a comprehensive data base management system for vegetation data, J. Veg. Sci., 2001, 12, 589-591

[24] McCune B., Grace J.B., Analysis of Ecological Communities, 2 ed., MjM Software Design, Glenden Beach, 2002

[25] Horvatić S., Phytogeographical characteristics and division of Yugoslavia [Fitogeografske značajke i rasčlanjenje Jugoslavije], Analitička flora Jugoslavije, 1967, 1, 23-61 (in Croatian)

[26] Hijmans R.J., Cameron S.E., Parra J.L., Jones P.G., Jarvis A., Very high resolution interpolated climate surfaces for global land areas, Int. J. Climatol., 2005, 25, 1965-1978

[27] Anonymous, Statistical year book of Yugoslavia 1989, Federal institute for statistics [Statistički godišnjak Jugoslavije, 1989, Savezni zavod za statistiku], Belgrade, 1989 (in Serbian)

[28] La Sorte F.A., McKinney M.L., Pyšek P., Compositional similarity among urban floras within and across continents: biogeographical consequences of human-mediated biotic interchange, Global Change Biol., 2007, 13, 913921

[29] Martinčič A., Wraber T., Jogan N., Podobnik A., Ravnik V., Turk B., et al., Small flora of Slovenia : determination key for ferns and seed plants [Mala flora Slovenije : ključ za določanje praprotnic in semenk], 4th ed., Tehniška založba Slovenije, Ljubljana, 2007 (in Slovene)

[30] Daisie (eds)., Handbook of alien species in Europe, Springer, Berlin, 2009 
[31] Flora Croatica Database, 2008, http://hirc.botanic. $\mathrm{hr} / \mathrm{fcd} /$

[32] Pignatti S., Bioindicator values of vascular plants of Flora of Italy [Valori di Bioindicazione delle Piante Vascolari della Flora d’Italia], Braun-Blanquetia, 2005, 39, 97

[33] Grime J. P., Plant strategies, vegetation processes and ecosystem properties, 2nd ed., J. Wiley \& Sons, Chichester, 2002

[34] Klotz S., Kühn I., Durka W., BIOLFLOR-a database of biological-ecological characteristics of Flora of Germany [BIOLFLOR-Eine Datenbank mit biologisch-ökologischen Merkmalen zur Flora von Deutschland], Schriftenreihe für Vegetationskunde, 2002, 38, 1-334 (in German)

[35] Tutin T.G., Heynard V.H., Burges N.A., Valentin D.H., Walters S.M., Webb D.A. (Eds.), Flora Europaea I-V, Cambridge University Press, Cambridge, 1964-1993

[36] Mucina L., Grabherr G., Ellmauer T., Plant communities of Austria, Part 1, Anthropogenic vegetation [Die Pflanzengesellschaften Österreichs, Teil 1, Anthropogene Vegetation], Gustav Fisher Verlag, Jena, 1993 (in German)

[37] ter Braak J.F.C., Šmilauer P., CANOCO Reference Manual and CanoDraw for Windows User's Guide to Canoco for Windows: Software for Canonical Community Ordination (version 4.5), Microcomputer Power (Ithaca, NY, USA), Ithaca, NY, USA, 2002

[38] De'ath G., Fabricius K.E., Classification and regression trees: A powerful yet simple technique for ecological data analysis, Ecology, 2000, 81, 3178-3192

[39] Breiman L., Friedman J., Stone C.J., Olshen R.A., Classification and Regression Trees, CRC Press LLC, Boca Raton, 1984

[40] Boršić I., Milović M., Dujmović I., Bogdanović S., Cigić P., Rešetnik I., et al., Alien flora of Croatia: proposals for standards in terminology, criteria and related database, Natura Croatica, 2008, 17, 55-71

[41] Pyšek P., Kučera T., Jarošík V., Plant species richness of nature reserves: the interplay of area, climate and habitat in a central European landscape, Global Ecol. Biogeogr., 2002, 11, 279289

[42] Celesti-Grapow L., Pyšek P., Jarošík V., Blasi C., Determinants of native and alien species richness in the urban flora of Rome, Diver. Distrib., 2006, 12, 490-501
[43] Celesti-Grapow L., Alessandrini A., Arrigoni P.V., Banfi E., Bernardo L., Bovio M., et al., Inventory of the non-native flora of Italy, Plant Biosyst., 2009, 143, 386-430

[44] Gasso N., Sol D., Pino J., Dana E.D., Lloret F., Sanz-Elorza M., et al., Exploring species attributes and site characteristics to assess plant invasions in Spain, Diver. Distrib., 2009, 15, 50-58

[45] Arianoutsou M., Bazos I., Delipetrou P., Kokkoris Y., The alien flora of Greece: taxonomy, life traits and habitat preferences, Biol. Invasions, 2010, 12, 3525-3549

[46] Pyšek P., Alien and native species in Central European urban floras: a quantitative comparison, J. Biogeogr., 1998, 25, 155-163

[47] Chocholoušková Z., Pyšek P., Changes in composition and structure of urban flora over 120 years: a case study of the city of PIzeň, Flora, 2003, 198, 366-376

[48] Holzner W., Weed species and weed communities, Vegetatio, 1978, 38, 13-20

[49] di Castri F., History of biological invasions with special emphasis on the Old World, In: Drake J.A., Mooney H.A., di Castri F., Groves R.H., Kruger F.J., Rejmánek M., et al., (Eds.), Biological invasions: a global perspective, John Wiley and Sons, Chichester, New York, Brisbane, Toronto, Singapore, 1989

[50] Kühn I., Klotz S., The alien flora of Germany-basics from a new German database, In: Child L., Brock J.H., Brundu G., Prach K., Pyšek P., Wade P.M., et al., (Eds.), Plant invasions: ecological threats and management solutions, Backhuys Publishers, Leiden, 2003

[51] Kowarik I., On the role of alien species in urban flora, In: Pyšek P., Prach K., Rejmánek M., Wade M. (Eds.), Plant invasions-global aspects and special problems, SPB Academic Publishing, Amsterdam, 1995

[52] Comin S., Poldini L., Archaeophytes: Decline and dispersal - A behavioural analysis of a fascinating group of species, Plant Biosyst., 2009, 143, S46-S55

[53] Chytrý M., Pyšek P., Wild J., Pino J., Maskell L.C., Vilà M., European map of alien plant invasions based on the quantitative assessment across habitats, Diver. Distrib., 2009, 15, 98107 